\title{
The Naya Pakistan Housing Policy: An Economic Analysis
}

\author{
Musirah Farrukh
}

Affordable housing is a common concern in developed and developing countries alike. In Pakistan, where the housing demand backlog is an astonishing 10 million units, housing shortage is a function of both quantity and affordability. To tackle the situation, in 2018 the government of Pakistan introduced the Naya Pakistan Housing Project with the stated aim to increase housing for the poor. This paper uses microeconomic theory to gauge the impact of two specific provisions proposed to be implemented under the Naya Pakistan Housing Project: allocation of public land for low-cost housing and promotion of low-income housing finance. It is argued that although theoretically, both provisions will not produce any dead-weight loss in the housing market and will result in increased consumption of housing, it is unclear whether they provide housing to the particularly needy segments of the population for which they were intended. It is recommended that further provisions are made to ensure that low-income borrowers are prioritized and protected from rent-seeking speculative buyers who are better positioned to take advantage of the Naya Pakistan Housing Project. The paper also recommends that Benazir Income Support Programmer's registry be used to disburse credit to needy segments. 
MUSIRAH FARRUKH is a second-year Master's of Public Policy candidate, concentrating on Economics and Trade Policy. She is the recipient of our Global Initiatives Tuition Fellowship, and her academic pursuits have been focused on practicing nonexperimental quantitative policy evaluation and design. Musirah has an undergraduate in Economics, from the Lahore University of Management Sciences (Pakistan), as well as a minor in Modern History. Her interest in Economics and Trade is derived from her interest in global development, connectivity and equity. Currently, she is working with the Macroeconomic Trade and Investment Group at the World Bank, on increasing Regional Connectivity in Central Asia.

\section{ACKNOWLEDGEMENTS}

The author would like to thank her father, Farrukh Azeem, for his undying support, her mother, Arsala Farrukh - my guiding light; Peter Duyshart, for putting up with my constant edits; Professor Anil Nathan for equipping me with all these ideas to analyze the world around me; Sydney and Katie for their comments and flexibility; and my friend Palwasha Faizan for sharing her industry insight. 


\section{INTRODUCTION}

Affordable housing is a common concern in developed and developing countries alike. In Pakistan, a dire housing shortage has been accruing critical mass over the past decade. Although a veteran political party in Pakistan, the Pakistan People's Party, is well known for its populist political slogan "Food, Clothes, and Housing (روثى، كيرّا، اور مكان)," it was the newly formed Pakistan Tehreek-e-Insaaf (PTI) party that highlighted and prioritized the housing issue. Before the 2018 General Elections, Imran Khan, Chairman of PTI party and candidate for Prime Minister, made a campaign promise to build five million homes. Khan won the election and became the Prime Minister of Pakistan, and subsequently announced the Naya Pakistan Housing Project to address the affordable housing situation.

As of 2021, this ambitious policy has made some progress to increase the supply and availability of affordable housing. This paper analyzes the housing situation in Pakistan and the pertinent policy solutions implemented by the PTI-led government. This paper uses microeconomic theory and the general equilibrium model to examine the State Bank of Pakistan's initiatives to increase housing finance as well as the government's initiative to provide public land for low-income housing. The paper finds that although the policies are a great initiative to address a dire situation, without properly targeting the lowest income households, the PTI-led government will be unable to achieve its stated goals to revitalize the economy and provide housing to the lowest income strata.

\section{DEFINING THE ISSUE: A BACKLOG OF DEMAND}

According to the 2017 census, the population of Pakistan stands at 210 million people-32 million households - making it the sixth most populous country in the world (Pakistan Bureau of Statistics (PBS) 2017). Several demographic trends have contributed to the emerging housing shortage in the country.

First, Pakistan's population growth rate is nearly exponential; the population growth rate in Pakistan is approximately 2.4 percent, significantly higher than China ( 0.54 percent), India (1.24 percent), and the United States (0.72 percent) (Javed and Khan 2018). Second, there is a rapidly growing trend towards urbanization. According to the United Nations Development Program in Pakistan, Pakistan is now the most urbanized country in South Asia (United Nations Development Program (UNDP) Pakistan 2019). To put this statistic in perspective, South Asia is home to both India and Bangladesh and has three of the ten largest metropolitan areas in the world (Macrotrends LLC 2021). However, this level of urbanization is a more recent phenomenon in Pakistan. According to the 1998 census, only 32.5 percent of Pakistanis lived in urban areas (PBS 1998); this proportion increased to 36.4 percent by 2017 (PBS 2017). While this appears to be a small increase, when one considers that Pakistan's population grew by 50 percent over the same time, it in fact means a large influx in the urban population. By 2025, almost 50 percent of Pakistanis are anticipated to reside in cities (United Nations Development Program (UNDP) Pakistan 2019). Population growth coupled with rural-tourban migration, which accounts for 20 percent of total migration to urban areas, has choked Pakistani cities and caused raging rent conditions and a housing shortage. Various sources estimate the current housing shortfall to be approximately 10.3 million units (State Bank of Pakistan 2019; Jabeen, Sheng and Aamir 2015; Dilawar 2018; Ahmed, Iqbal and Mustafa 2020). Given the demographic trends and decreasing household size (Pakistan Bureau of Statistics 2018-19; Javed and Khan 2018), it can be expected that the housing deficit will 
continue to rise. Housing demand is projected to grow to 17.2 million housing units by 2025 (Naqvi 2020; Iqbal 2020).

The housing shortage is felt most among the two lowest income quintiles: 87 percent of those in the lower income quintiles struggle to find housing compared to only 10 percent of higher income quintiles (Hasan and Arif 2018). Fifty-five percent of the population in the City of Karachi, the largest city in Pakistan, lives in urban slums (United Nations Development Program (UNDP) Pakistan 2019). One study notes that, "households in the bottom 68 percent of the income distribution can afford just 1 percent of the available housing, whereas households in the top 12 percent can afford 56 percent of the available housing" (Malik, et al. 2020, 256). Seeing that the crisis is more acute due to the lack of housing provision for the lowest income groups, it can be understood that the housing crisis in Pakistan is both a function of quantity and affordability.

To address the situation, PTI proposed the Naya Pakistan Housing Policy in its election manifesto. As part of an economic revitalization plan, PTI promised to build five million homes in five years. In 2018, PTI won the General Elections and formed a new government. Thereafter, the new Prime Minister of Pakistan formally launched the Naya Pakistan Housing Project on October 10, 2018 in a bid to not just spur the crippled economy, but also to give respite to lowest income groups in society, with the Prime Minister saying, "the target of this [plan] is the common man, who could not even think about owning a house" (Dawn 2018).

\section{NAYA PAKISTAN HOUSING PROJECT}

It should be noted that there is no singular policy document to outline the Naya Pakistan Housing Project. However, an understanding of the scope of the Naya Pakistan Housing Project was established through the information revealed by Prime Minister Imran Khan in his inaugural speech of the venture (Jabri 2018; Dawn 2018), as well as through PTI's manifesto (Pakistan Tehreek -e- Insaaf 2018b) and policy documents available on PTI's party website (Pakistan Tehreek -e- Insaaf 2018a).

The housing project utilizes a public-private partnership structure (Jabri 2018). To address the demand side of the housing crisis, the government intends to increase consumer borrowing by improving access to financing options, such as long-term loans, to ensure affordability of housing units. To increase housing supply, the federal and provincial governments provide some of their publicly owned parcels of land to developers (Jabri 2018; Pakistan Tehreek -e- Insaaf 2018a). By reducing the cost of production for housing developers by diminishing land acquisition costs, government land provision is meant to incentivize more developers and contractors to build low-income housing infrastructure. Under this agreement, the price of land is ultimately recovered from the end consumer, as opposed to the developer (Pakistan Tehreek -e- Insaaf 2018a). The developers use their own funds for construction but benefit from the economies of scale that result from the utilization of standardized design. The government also promised to facilitate the provision of utilities such as gas, water, and electricity for developers and future homeowners alike. Additionally, the government aims to streamline processes by cutting down approval times on zoning and permitting requests.

In summation, the housing policy stands on three pillars:

1. Improving access to loans for housing finance by increasing long-term loans 
2. Providing public land to builders for immediate construction

3. Facilitating the housing schemes through timely approvals and provision of utilities

This paper focuses particularly on government initiatives to improve access to home financing as well as the provision of public land to developers.

\section{THE STATE BANK LOAN POLICY}

There are multiple mechanisms in microeconomic theory that support the idea of subsidizing loans to entice people to purchase homes. In an intertemporal choice-a choice where an individual's future consumption is affected by current consumption decisionsincreasing borrowing in the current period increases consumption in the current period (Nechyba 2016). Thus, in any credit scheme, increasing credit access fosters greater consumption because it allows an individual to consume more than their current budget would in the current period. This shows that under the intertemporal choice model, increasing credit for home financing could have a positive effect on increasing access to housing. Further, both substitution and income effects will work to increase consumption of housing according to the consumer choice model, since the loan scheme reduces the cost of housing. Due to the substitution effect - which dictates that when the price of a product falls, consumption of the product will rise-increased access to loans should enable people to consume more housing. Additionally, economists consider housing to be a normal good, meaning it is a type of good where consumption will increase when income increases. The income effect dictates that a fall in the price of a normal good will result in an increase in well-being and will therefore result in more consumption overall. Since housing is a normal good, the income effect will also cause an increase in consumption of housing when the price of housing drops (Nechyba 2016).

The Pakistani government's loan scheme works as a matching grant, which is a conditional grant where the government promises to pay a specific portion of the cost of a service or good. At the behest of the Federal Government, the State Bank of Pakistan - a central bank similar to the Federal Reserve in the US - has launched a comprehensive policy to increase housing finance, using a host of policy tools. This includes a relaxation of regulations to increase liquidity for banks to invest in housing finance (State Bank of Pakistan 2019) and a reduction in the General Reserve Requirement for banks, particularly for banks' low-cost housing finance portfolio. The General Reserve Requirement requires banks to hold a certain amount in reserve to ensure they can meet their liabilities in case of withdrawals. By not requiring banks to hold on to as much money for reserve, it should encourage banks to increase investment in low-cost housing finance, ultimately benefiting low-cost housing borrowers by making more funds available for them.

Another significant measure taken by the State Bank is to exclude low-cost housing finance from the ten percent banking cap on real estate investment (State Bank of Pakistan 2019). A cap on investment refers to the maximum exposure in a market a lender is allowed to have; in this case, the State Bank has limited investment by banks in the real estate market. However, the policy excludes investment in low-cost housing finance from this limit, providing an opportunity for banks to increase their investment in this part of the real estate market. This could potentially favor low-income loan seekers as it could enable more resources to be allocated into the low-income housing finance market. 
The State Bank of Pakistan also announced its own facility for low-cost housing for special segments of the population, such as widows, children of martyrs, transgender people, and people from areas severely affected by terrorism. These populations will be given a total of 100,000 loans at a borrowing rate of five percent for up to 12.5 years for an amount up to PKR 2.7 million (State Bank of Pakistan 2019). Although it is commendable that the State Bank is looking to assist previously neglected communities, it should have also included Benazir Income Support Program (BISP) beneficiaries. BISP is Pakistan's social safety net and has a directory for the most vulnerable people in Pakistan. This directory, which was established under the supervision of the World Bank (and so has been scrutinized both nationally and internationally before being used to disburse funding to low-income households) can easily be leveraged to target vulnerable populations in dire need of housing finance.

Furthermore, according to the Pakistan Standard of Living Measure (PSLM) Survey conducted in 2017, 24 percent of the monthly expenditures of Pakistanis is spent on housing and utilities (PBS 2018-19). If a family borrowed the maximum PKR 2.7 million for 12.5 years, they would have to make a monthly mortgage payment of PKR 24,243 per month. ${ }^{1}$ At this rate, someone who is able to pay PKR 24,243 would be making approximately PKR 100,000. However, the average monthly income of the fifth (highest) quintile is PKR 63,544 and that of the fourth quintile is PKR 37,643 (PBS 2018-19) - revealing that only relatively high-earning individuals will be able to afford this loan at the given rates. Table 1 shows what loan amount each income group should be able to afford. As noted earlier, the housing crisis is particularly acute within the lowest two income groups. The average monthly income of a person in the first income quintile is PKR 23,192. A person in the first income quartile will be able to make a monthly payment of about PKR 5,500, and can borrow an amount of PKR 500,000 under this loan scheme. Similarly, the average monthly income of someone in the second income quintile is PKR 29,049, and they can make a monthly payment of about PKR 7,000, affording a loan of about PKR 800,000.

Seeing that the maximum loan of PKR 2.7 million is well above the reach of even the highest income quintile, the State Bank should do more to ensure they meet their goal of expanding credit to the lowest income stratum. One potential policy to address this matter is to significantly reduce the maximum loanable amount to ensure that the most financially vulnerable members of society are targeted. For example, if the maximum loan amount was PKR 1 million, the policy may be more likely to target the lowest two income strata because they would be able to afford the monthly payments.

\footnotetext{
${ }^{1}$ The monthly payment value of PKR 24,243 has been calculated using Habib Bank Limited's amortization schedule. Habib Bank Limited is the largest bank in Pakistan.
} 
Table 1: Loan amount afforded by each income quintile

\begin{tabular}{|l|l|l|l|}
\hline Quintile & $\begin{array}{l}\text { Monthly } \\
\text { Income } \\
(\text { PKR) }\end{array}$ & $\begin{array}{l}\text { Monthly } \\
\text { Expenditure on } \\
\text { Housing } \\
(\text { PKR) }\end{array}$ & $\begin{array}{l}\text { Maximum Affordable Total } \\
\text { Loan Amount } \\
(\text { PKR) }\end{array}$ \\
\hline 1 (lowest) & 23,192 & $\mathbf{5 , 5 6 6 . 0 8}$ & $\mathbf{6 1 9 , 9 0 0}$ \\
\hline $\mathbf{2}$ & $\mathbf{2 9 , 0 4 9}$ & $\mathbf{6 , 9 7 1 . 7 6}$ & $\mathbf{7 7 6 , 5 0 0}$ \\
\hline $\mathbf{3}$ & $\mathbf{3 1 , 3 7 3}$ & $\mathbf{7 , 5 2 9 . 5 2}$ & $\mathbf{8 3 8 , 6 0 0}$ \\
\hline $\mathbf{4}$ & $\mathbf{3 7 , 6 4 3}$ & $\mathbf{9 , 0 3 4 . 3 2}$ & $\mathbf{1 , 0 0 6 , 1 0 0}$ \\
\hline $\mathbf{5}$ (highest) & $\mathbf{6 3 , 5 4 4}$ & $\mathbf{1 5 , 2 5 0 . 5 6}$ & $\mathbf{1 , 6 9 8 , 4 0 0}$ \\
\hline
\end{tabular}

${ }^{l}$ Source: PSLM 2017 (PBS 2018-19, 35).

${ }^{2}$ Source: Calculated as 24 percent of monthly income, since PSLM 2017 indicates that $24 \%$ of the monthly consumption of Pakistanis is spent on housing and utilities (PBS 2018-19, 36).

${ }^{3}$ Source: Calculated using Habib Bank Limited's amortization schedule.

Furthermore, the number of beneficiaries is capped at 100,000 borrowers for this facility. Pakistan is a country of 210 million people, with at least 24.3 percent of the population living under the national poverty line; this translates to almost 51 million people living in abject poverty (Asian Development Bank n.d.). As noted earlier, the demand for housing falls short by approximately 10 million homes. Compared to demand, 100,000 available loans is quite underwhelming. Although the policy is ambitious and could possibly benefit a large number of low-income borrowers, limiting the number to only 100,000 borrowers makes little sense considering the scale of the intervention required to fulfill the housing demand shortage.

\section{PROVISION OF LAND}

The ratio of house price-to-income in Pakistan is 18.76:1 - a far cry from the United States' ratio of 4.18:1 (Towergate Insurance). There is a severe housing shortage in the United States as well, illustrating just how dire the situation is in Pakistan. A key contributing factor to the high price of housing is the ever-rising price of urban land. Urban land has been attracting speculative buyers and developers in Pakistan since the 1990s when suburban or peri-urban land began to be developed and repackaged as urban land. The success of builders repackaging suburban land as urban land and the subsequent rise in land value has attracted additional buyers. The result is sharply increasing plot prices. From 2012 to 2020, urban land prices rose 160 percent (Zameen 2020) and are expected to continue to increase.

Recognizing the high price of land, the government's initiative to provide public land in urban areas for low-income housing could revitalize the affordable and inclusionary housing markets. Providing public land for this purpose will lower the average costs for builders, increasing their profit margins. Higher profits should encourage more builders to enter the 
market, thereby increasing total supply. Increased housing supply would also drive down market prices, making housing more affordable. For suppliers, the provision of land works as a subsidy, reducing average costs and increasing mark-up.

According to microeconomic theory, because the cost of the land should be recovered in the long run from the consumers, in the short-term, the land policy acts as a subsidy from the government in the form of reduced housing costs. As discussed, the intertemporal model of consumer choice dictates that affordability of housing in the current period will rise as borrowing rises. This means that consumers will have more income at their disposal in the current period, which allows them to afford more housing in the current period. Thus, in the short-run, provision of land by the government should increase demand for housing (in the long-run, however, consumption may be affected as people attempt to pay back loans over future periods). The plan to give land to developers for free while charging buyers is sound economic policy because enabling developers to earn a profit will decrease the odds of a market failure. Since the government is not actually expending capital when providing land to the developers and is not providing direct subsidies to the low-income households, the policy ensures that no deadweight loss exists.

\section{SUMMARY OF POLICY LIMITATIONS}

The loan policy, coupled with the provision of land, is set to ensure that both demand and supply forces work together to ensure greater availability of housing at the lowest income strata. However, there is nothing in the land or loan policies to ensure that the poorest income groups will benefit from it. As noted above, the ceiling price point of PKR 2.7 million as the loan amount is set to benefit only the highest income groups. Apart from capping the value of the final property being sold at no more than PKR 3 million, the government has not included or implemented any provisions to ensure that speculative buyers will not enter the market. Even more concerning is that the real estate market in Pakistan is already rife with speculative buying. Returns in the real estate market have been high historically-residential property, plots of land, and houses have all seen a consistent upward trend (Zameen 2020) The low risk of investment due in part to low volatility of prices has ensured that investors, both small and large scale, have continued to invest in the real estate market.

Rent prices in Pakistan have also skyrocketed as the population continues to concentrate in urban areas. Over the past five years, rent prices have increased by as much as 180 percent in residential areas (Hanif 2017). Both the continued rise of urban property prices and rent, as well as the trend of greater urbanization in Pakistan, increase the likelihood that speculative investors could take advantage of the Naya Pakistan Housing Policy and the market conditions that it creates. Speculators can wait for property prices to rise over time or can rent properties to earn increased profits over time. This means that the government must implement additional measures to ensure that only those in need are able to get access to this housing and safeguard against speculative buying. Buyers who can afford to buy multiple houses should not be allowed to invest in the housing scheme, as this could likely raise prices for low-income housing units if unchecked.

\section{CONCLUSION}


Economic factors and urban trends provide justification for the Pakistani government to intervene in the housing market. It is commendable that the PTI government brought this issue - which affects almost 78 percent of Pakistan's population - to the forefront of policy priorities. Revitalizing the housing industry while focusing on the lowest-income strata could be transformational for the Pakistani economy.

However, as this paper highlights, a more targeted policy is required to ensure that the right segments of society benefit from the government's intervention. Particularly, the State Bank of Pakistan's regulations can be tightened to ensure the lowest income stratum is benefiting from the loan structure. The maximum loan amount of PKR 2.7 million is too high, as shown in the analysis, and should be decreased so that it is more affordable for lower-income households. Similarly, the 100,000 cap on the number State Bank loans may be too little to contend with the overwhelming demand of millions of Pakistanis in need. Although the State Bank of Pakistan has excluded home financing from real estate exposure for banks, they have not made any additional provisions to show that the lowest-income loan applicants are prioritized. The market is rife with speculators, with even the market for rental property booming. Focusing government resources, such as land, on this market is a promising initiative; however, the government should ensure that it does not add to the woes and inequities of the poor by extending loans that only enable the rich to own homes while the poor can only rent. The state should leverage targeting platforms erected by Pakistan's social safety net programs and utilize existing data on vulnerable populations. As mentioned earlier, Benazir Income Support Program has quality data on the most vulnerable segments of society, which can easily be leveraged to target the lowest two income groups who are most in need of housing.

There is no doubt that there is a serious lack of distributional equity in the housing market in Pakistan. Too much housing is available for the rich and too little is available for the poor. The Naya Pakistan Housing Project is a commendable effort that sheds light on a greatly neglected and festering issue. However, the government needs to do more to ensure that government land and revenue are utilized for the benefit of those who need it the most. 


\section{REFERENCES}

Ahmed, Ayaz, Nasir Iqbal, and Ghulam Mustafa. 2020. Measuring the Impact of Remittances on Housing Demand: Evidence from Large Cities in Pakistan. Pakistan Institute of Development Economics. Accessed December 2020. https://www.pide.org.pk/pdf/Working\%20Paper/WorkingPaper-2020-10.pdf.

Asian Development Bank. n.d. Country Profile: Pakistan. Asian Development Bank. Accessed December 2020. https://www.adb.org/countries/pakistan/poverty.

Associated Press Pakistan. 2020. World Bank hails Pakistan's cash scheme for poor. May 05. Accessed February 2021. https://tribune.com.pk/story/2214909/1-world-bankhails-pakistans-cash-scheme-poor.

Brauw, Kate Ambler and Alan de. 2017. The Impacts of Cash Transfers on Women's Empowerment: Learning from Pakistan's BISP Program. Discussion Paper No. 1702. February. Accessed December 2020.

http://documents1.worldbank.org/curated/en/840271488779553030/pdf/113161-WPP103160-PUBLIC-Social-Protection-Labor-no-1702.pdf.

Dawn. 2018. 'I will steer you out of this difficult time': PM Khan addresses economic uncertainty. October 10. Accessed December 2018. https://www.dawn.com/news/1438116.

Dilawar, Ismail. 2018. Urban Housing Crisis Deepens With Pakistan's Financial Woes. December 26. Accessed December 2020.

https://www.bloomberg.com/news/articles/2018-12-26/urban-housing-crisis-deepenswith-pakistan-s-financial-woes.

Hanif, Usman. 2017. Our real estate and the Chinese. Profit. September 25. Accessed December 2020. https://profit.pakistantoday.com.pk/2017/09/25/our-real-estate-andthe-chinese/.

Hasan, Arif, and Hamza Arif. 2018. "Pakistan: the causes and repercussions of the housing crisis." IIED Working Paper. International Institute for Environment and Development. October. Accessed December 2020. https://pubs.iied.org/pdfs/10864IIED.pdf.

Iqbal, Dr. Nasir. 2020. Sustainable housing. March 18. Accessed December 2020. https://www.thenews.com.pk/print/630789-Iqbal.

Jabeen, Azra, Huang Xi Sheng, and Muhammad Aamir. 2015. "Housing Crises in Pakistan: Review of Population Growth and Deficiencies in Housing Laws and Policies." International Journal of Sciences: Basic and Applied Research (IJSBAR) 24, No. 3: 323-347. https://nphp.com.pk/wpcontent/uploads/2019/07/ACASH\%20Research/Pakistan\%20Housing\%20Crises\%20in\%20Pakistan, \%20Review\%20of\%20Population $\% 20 \mathrm{Gr}$ owth.pdf. 
Jabri, Parvez. 2018. PM launches housing programme to build 5 million affordable units. Business Recorder. Oct 11. Accessed 2018 Dec.

https://www.brecorder.com/news/445070.

Javed, Dr. Nasir, and Maira Khan. 2018. "Urban Gazette." Analysis. Urban Unit. Accessed December 2020. https://www.urbanunit.gov.pk/Upload/Photos/population.pdf.

Macrotrends LLC. 2021. Largest World Cities by Population. Accessed Feb 2021. https://www.macrotrends.net/cities/largest-cities-by-population.

Malik, Sana, Ruhizal Roosli, Fariha Tariq, and Nor'aini Yusof. 2020. "Policy Framework and Institutional Arrangements: Case of Affordable Housing Delivery for Low Income Groups in Punjab, Pakistan." Housing Policy Debate 30, No. 2, 243-268: DOI: $10.1080 / 10511482.2019 .1681018$.

Naqvi, Hassan. 2020. Pakistan's housing backlog touches 10.3m mark. Profit. March 7. Accessed December 2020. https://profit.pakistantoday.com.pk/2020/03/07/pakistanshousing-backlog-touches-10-3m-mark/.

Nechyba, Thomas. 2016. Microeconomics: an intuitive approach with calculus. Nelson Education. Boston: Cengage Learning.

Pakistan Bureau of Statistics (PBS). 1998. "Area, Population, Density, and Urban/Rural Proportion by Administrative Units." Population and Housing Indicators Population Census 1998. Population Census 1998. Accessed December 2020.

http://www.pbs.gov.pk/sites/default/files//tables/AREA\%20POPULATION\%20DEN SITY\%20AND\%20URBAN\%20RURAL\%20PROPORTION.pdf.

PBS. 2018-19. Pakistan Social and Living Standards Measurement (PSLM). Accessed December 2020.

https://www.pbs.gov.pk/sites/default/files//pslm/publications/pslm hies 201819 provincial/key findings report of plsm hies 2018 19.pdf.

PBS. 2017. "Provisional District Wise Census Results Census." Pakistan Bureau of Statistics. Ministry of Statistics. Accessed December 2020.

https://www.pbs.gov.pk/sites/default/files//press releases/2017/Population Census 2 $\underline{017 \text { Results.pdf. }}$

Pakistan Tehreek-e-Insaaf. 2018a. "Naya Pakistan Housing Project - Corner Stone Of PTI's Economic Uplift." Pakistan Tehreek-e-Insaaf (Official Website). Accessed December 2018. https://insaf.pk/news/naya-pakistan-housing-program-corner-stone.

Pakistan Tehreek -e- Insaaf. 2018b. "PTI Manifesto 2018: The Road to Naya Pakistan." Pakistan Tehreek-e-Insaaf (Official Website). Accessed December 2018. https://pmo.gov.pk/documents/manifesto-pti.pdf.

State Bank of Pakistan. 2019. Policy for Low Cost Housing Finance. Housing \& SME Finance Infrastructure. March. Accessed December 2020. https://www.sbp.org.pk/smefd/PolicyLowCostHousingFin.pdf. 
Towergate Insurance. n.d. House Price Vs. Income - Where can you Afford to Buy? Accessed December 2020. https://www.towergateinsurance.co.uk/commercialproperty-insurance/house-price-income-ratio.

United Nations Development Program (UNDP) Pakistan. 2019. "Sustainable Urbanisation." Development Advocate 5, No. 4. Accessed December 2020. https://www.pk.undp.org/content/pakistan/en/home/library/development policy/dapvol5-iss4-sustainable-urbanization.html.

World Bank. 2017. Pakistan: Social Safety Net Project. Accessed February 2021. https://projects.worldbank.org/en/projects-operations/project-detail/P103160.

Zameen.com. 2020. Pakistan Plots Price Index. Zameen.com. October. Accessed December 2020. https://www.zameen.com/index/buy/plots/. 